\title{
Crystalline lipid keratopathy in anterior sclerokeratitis
}

\author{
Geeta Behera 다, ${ }^{1}$ Malavika Mani, ${ }^{1}$ Ninan Palamootil Jacob ํㅏ, ${ }^{1}$ Murugesan Vanathi ${ }^{2}$
}

${ }^{1}$ Department of Ophthalmology, Jawaharlal Institute of

Postgraduate Medical Education and Research (JIPMER),

Puducherry, Puducherry, India

${ }^{2}$ Dr. Rajendra Prasad Centre for Ophthalmic Sciences, All India Institute of Medical Sciences (AllMS), New Delhi, Delhi, India

\section{Correspondence to} Dr Geeta Behera;

geeta.anandaraja@gmail.com

Accepted 16 July 2021
Check for updates

(C) BMJ Publishing Group Limited 2021. No commercial re-use. See rights and permissions. Published by BMJ.

To cite: Behera G, Mani M, Jacob NP, et al. BMJ Case Rep 2021;14:e244353. doi:10.1136/bcr-2021244353

\section{DESCRIPTION}

A 29-year-old woman presented with spontaneousonset redness, pain, photophobia and diminution of vision in her right eye; best-corrected visual acuity (BCVA): 20/80. Examination revealed diffuse anterior scleritis with scleral thinning, near-total interstitial corneal haze and paracentral stromal crystal-like deposit $(2 \times 2 \mathrm{~mm})$, with adjoining fine deep vessels arising from the nasal limbus (arrow, figure $1 \mathrm{~A}, \mathrm{~B}$ ). Bluish-grey appearance due to scleral thinning was most marked inferotemporally (arrow, figure 1C). The left eye had mild anterior scleritis; BCVA: 20/20 (figure 1D). Her intraocular pressure (IOP) was; $13 \mathrm{~mm} \mathrm{Hg}(\mathrm{OD}), 17 \mathrm{~mm} \mathrm{Hg}$ (OS). Immunological investigations were negative for rheumatoid factor, antinuclear antibodies, antineutrophil cytoplasm antibody, anticyclic citrullinated peptides, HLA B-27, venereal disease research laboratory test, toxoplasma serology with normal complete haemogram, chest X-ray, thyroidstimulating hormone; raised erythrocyte sedimentation rate $(72 \mathrm{~mm} /$ hour $)$, high sensitivity $\mathrm{C}$ reactive protein $(6.89 \mathrm{mg} / \mathrm{L})$, negative PCR of blood and conjunctival swab for herpes simplex virus.

She received oral prednisolone $60 \mathrm{mg} /$ day (tapered $10 \mathrm{mg} /$ week for 6 weeks and stopped), right eye, topical prednisolone acetate $1 \% 4$ hourly and lubricant (carboxymethylcellulose $0.5 \%$ ) therapy. The concentric interstitial haze in the paracentral cornea decreased with improvement in BCVA $(20 / 30)$ and scleritis resolved, after 1 month. The central crystalline lipid deposit, adjoining the new vessels nasally, increased (figure $2 \mathrm{~A}$ ). She is advised
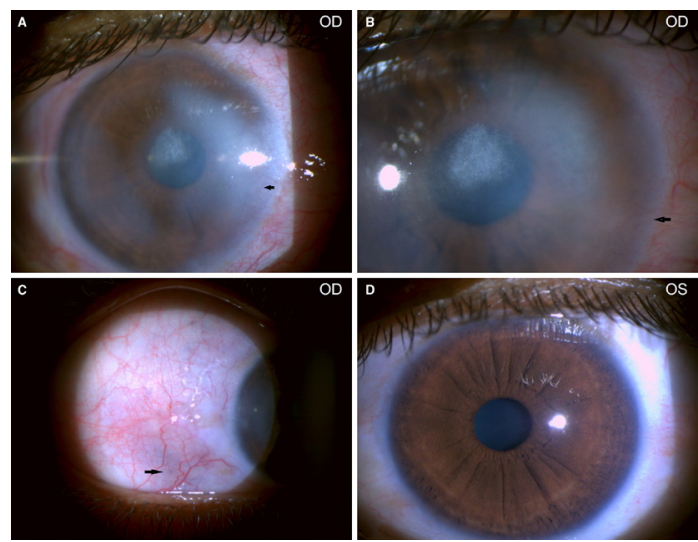

Figure 1 Slit-lamp photograph (OD). (A, B) At presentation, showing fine crystal-like lipid deposit with refractile bodies in the central cornea with concentric paracentral haze and fine neovascular frond arising from the nasal limbus (arrow) and anterior scleritis. (C) Diffuse anterior scleritis with the bluish-grey appearance of inferotemporal sclera due to scleral thinning (arrow) (D) (OS) normal anterior segment.
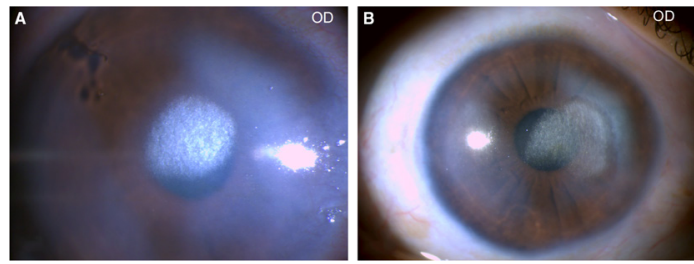

Figure 2 Slit-lamp photograph (OD) (A) at 1 month, with an increase in the crystal-lipid deposit, adjoining corneal neovascularisation (arrow). (B) At 1 year, increase in the deposit in a fan-shaped pattern towards the nasal part of the cornea.

topical steroids (topical prednisolone acetate 1\%, three times a day) to date ( $1 \frac{1 / 2}{2}$ years), to prevent inflammatory exacerbation. However, the central lipid keratopathy has increased progressively nasally, replacing the interstitial haze (figure 2B). It is seen as a white fan-shaped crystalline opacification with refractile bodies in the stroma $(4 \times 5$ $\mathrm{mm})$, temporal to the deep vascular frond arising from the nasal limbus (figure 2B) (BCVA: 20/20, IOP: $12 \mathrm{~mm} \mathrm{Hg}$ ). This progression is also noted on anterior segment optical coherence tomography (AS-OCT) in the deep corneal stroma; clear areas overlying the pathology indicative of vessels (arrowheads, figure 3A,B). The neovascularisation seems to be causing progressive crystal-like keratopathy. Central corneal thickness is $532 \mu \mathrm{m}$ (OD) and $562 \mu \mathrm{m}(\mathrm{OS})$; the thinnest corneal point being superonasal periphery (between 5 and $7 \mathrm{~mm}$ ): $311 \mu \mathrm{m}$ (OD) measured with AS-OCT (figure 3C). At the last follow-up, she received a subconjunctival injection of bevacizumab $(1.25 \mathrm{mg} / 0.05 \mathrm{~mL})$.

Crystalline keratopathy with anterior sclerokeratitis has been reported earlier. ${ }^{1}$ Secondary lipid keratopathy following inflammatory keratitis with neovascularisation is usually of herpetic origin, though reported with bilateral scleritis, too. ${ }^{2}$ Neovascularisation is considered pathognomonic in secondary lipid keratopathy, as lipoproteins leaking from new vessels cause it. ${ }^{2}$ Topical and subconjunctival injection of anti- vascular endothelial growth factor (VEGF) has demonstrated positive results. ${ }^{4}$ Fine-needle diathermy and intravascular mitomycin C injections are important future therapies. ${ }^{2}$ Crystalline lipid deposit is seen in primary lipid keratopathy (Schnyder's crystalline dystrophy), its pathophysiology being unclear. ${ }^{5}$ Unilateral crystalline keratopathy in infectious keratitis is well described. ${ }^{6}$ Other secondary causes of crystalline keratopathies such as monoclonal gammopathy and cystinosis are typically bilateral. ${ }^{78}$ We highlight the appearance of crystalline secondary lipid keratopathy in anterior sclerokeratitis through our case. The region of the cornea with new deep vessels 

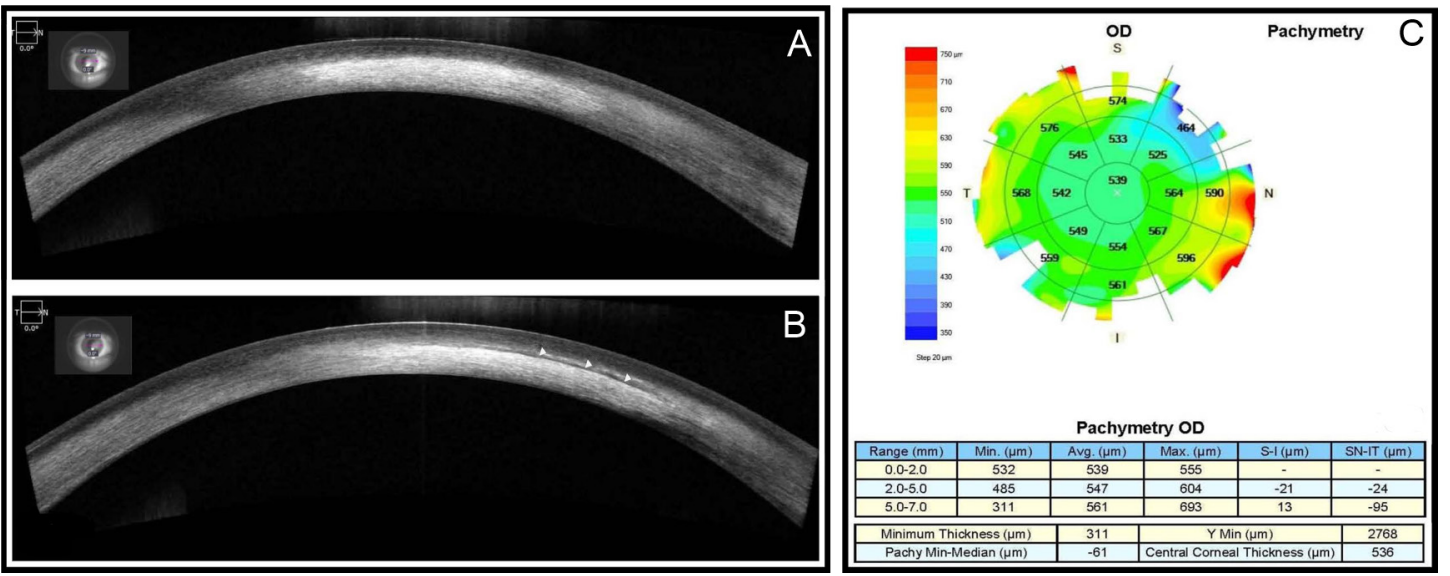

Figure 3 (A) AS-OCT images at 3 months (upper panel) and (B) 1 year (lower panel) showing the increase in deep stromal deposit underlying clear areas that denote new vessels (white arrowheads). (C) Pachymetry map (OD) with areas of peripheral thinning on AS-OCT (anterior segment optical coherence tomography).

showed progressive crystal-like lipid keratopathy, though inflammatory haze involved the entire cornea. There may be an overlap of crystalline morphology in postinflammatory secondary lipid keratopathy, appearing like Schnyder's crystalline dystrophy. ${ }^{5}$

\section{Patient's perspective}

I don't have any pain, watering, or irritation at present. Eye is fine, but vision is less in that eye. I am using drops regularly.

\section{Learning points}

- Secondary lipid keratopathy is seen in the presence of inflammation and corneal neovascularisation.

- The crystalline morphology of lipid deposits may be seen in secondary lipid keratopathy, like primary lipid keratopathy.

Contributors GB, MV, NPJ and MM examined the patient and GB and MV treated the patient. All authors wrote the manuscript and approved it for publication

Funding The authors have not declared a specific grant for this research from any funding agency in the public, commercial or not-for-profit sectors.

Competing interests None declared.
Patient consent for publication Obtained.

Provenance and peer review Not commissioned; externally peer reviewed.

\section{ORCID iDs}

Geeta Behera http://orcid.org/0000-0003-0893-9090

Ninan Palamootil Jacob http://orcid.org/0000-0003-1760-8568

\section{REFERENCES}

1 Gupta N, Ganger A, Bhartiya S, et al. In vivo confocal microscopic characteristics of crystalline keratopathy in patients with sclerokeratitis. Ocul Immunol Inflamm 2018:26:700-5.

2 Hall MN, Moshirfar M, Amin-Javaheri A, et al. Lipid keratopathy: a review of pathophysiology, differential diagnosis, and management. Ophthalmol Ther 2020;9:833-52.

3 Morisawa M, Yamagami S, Inoki T, et al. Bilateral centripetal lipid keratopathy with diffuse anterior scleritis. Acta Ophthalmo/ Scand 2003;81:202-3

4 Roshandel D, Eslani M, Baradaran-Rafii A, et al. Current and emerging therapies for corneal neovascularization. Ocul Surf 2018;16:398-414.

5 Crispin S. Ocular lipid deposition and hyperlipoproteinaemia. Prog Retin Eye Res 2002:21:169-224.

6 Porter AJ, Lee GA, Jun AS. Infectious crystalline keratopathy. Surv Ophthalmol 2018:63:480-99.

7 Moshirfar M, West W, Ronquillo Y. Paraproteinemic Keratopathy. In: StatPearls [Internet]. Treasure Island (FL): StatPearls Publishing, 2021.

8 Tsilou ET, Rubin BI, Reed GF, et al. Age-Related prevalence of anterior segment complications in patients with infantile nephropathic cystinosis. Cornea 2002;21:173-6.

Copyright 2021 BMJ Publishing Group. All rights reserved. For permission to reuse any of this content visit

https://www.bmj.com/company/products-services/rights-and-licensing/permissions/

BMJ Case Report Fellows may re-use this article for personal use and teaching without any further permission.

Become a Fellow of BMJ Case Reports today and you can:

- Submit as many cases as you like

- Enjoy fast sympathetic peer review and rapid publication of accepted articles

- Access all the published articles

- Re-use any of the published material for personal use and teaching without further permission

Customer Service

If you have any further queries about your subscription, please contact our customer services team on +44 (0) 2071111105 or via email at support@bmj.com.

Visit casereports.bmj.com for more articles like this and to become a Fellow 